\title{
Flow rate changes of drippers with dilutions of treated water produced by oil exploration in the Brazilian semiarid region*
}

\author{
Hudson Salatiel Marques Vale ${ }^{1^{* *}}$, Danniely de Oliveira Costa ${ }^{1}$, Rafael Oliveira Batista ${ }^{1}$, Luis Cesar de Aquino \\ Lemos Filho ${ }^{1}$, Mychelle Karla Teixeira de Oliveira ${ }^{2}$, Francisco de Assis de Oliveiraa ${ }^{1}$, Marcelo Tavares Gurgel ${ }^{2}$, \\ Joaquim Odilon Pereira ${ }^{1}$, Jeane Cruz Portela ${ }^{2}$, Marineide Jussara Diniz ${ }^{1}$, Blake Charles Diniz Marques ${ }^{1}$, \\ Francisca Evânia de Carvalho ${ }^{1}$, Ana Luiza Veras de Souza ${ }^{1}$
}

\author{
${ }^{1}$ Universidade Federal Rural do Semi-Árido, Departamento de Engenharia e Ciências Ambientais, 59625-900, Mossoró - \\ RN, Brazil \\ ${ }^{2}$ Universidade Federal Rural do Semi-Árido, Departamento de Ciências Agronômicas e Florestais, 59625-900, Mossoró - \\ RN, Brazil
}

\begin{abstract}
*Work extracted from the doctoral thesis of the first author.
**Corresponding author: rafaelbatista@ufersa.edu.br
\end{abstract}

\begin{abstract}
The liquid residue called "produced water" from the exploitation of oil in the ground and sea is generated in large volumes and has significant polluting potential. In the Brazilian semiarid region, this liquid can be applied to the agricultural lands, if properly treated and applied to the soil by dripping. It is an alternative that can mitigate water scarcity and impacts on the environment. However, the vulnerability of drippers to clogging is a problem and can be mitigated with the dilution technique. The flow rate changes of drippers for the application of dilutions of produced water treated (PW) with underground water (UW) was analyzed. The experiment was conducted in a completely randomized split-split-plot design with three replications. Plots consisted of treatments (D1: 100\% of UW, D2: 90\% of UW and $10 \%$ PW, D3: $80 \%$ of UW and $20 \%$ of PW, D4: $70 \%$ of UW and $30 \%$ of PW and D5: $60 \%$ of UW and $40 \%$ of PW). The split-plots consisted of types of drippers (G1: $\left.1.6 \mathrm{~L} \mathrm{~h}^{-1}, \mathrm{G} 2:-1.6 \mathrm{~L} \mathrm{~h}^{-1}, \mathrm{G} 3: 1.7 \mathrm{~L} \mathrm{~h}^{-1}\right)$ and split-split-plots consisted of evaluation times $(0,40,80,120$ and $160 \mathrm{~h})$. Flow rate (D) and flow rate coefficient of variation (FCV) were taken every 40 hours untill $160 \mathrm{~h}$. The results showed that the G3 emitter was the most resistant to clogging. The dilutions D2 and D3 provided the lowest losses in hydraulic performance in the drip units. The highest rates of clogging occurred in the $\mathrm{G} 2$ emitter operating in the D5 dilution.
\end{abstract}

Keywords: Reuse, petroleum, emitters, clogging, dilution.

Abbreviations: PW_Produced water; UW_Underground water; F_Flow rate; FCV_Flow rate coefficient of variation; EC_Electric conductivity; SS_Suspense solids; DS_Dissolved solids; TDR_Totally randomized design.

Introduction

The intensification of water scarcity is a problem that is being faced worldwide (Bichai et al., 2012). Brazil has a large amount of fresh water, but most of the reserves are concentrated in the Amazon region, while other regions bordering the Atlantic Ocean, especially the Northeast, have low water availability (Bressiani et al., 2015).

The causes of water scarcity are a combination of several factors such as inefficient water distribution, no emergency plan or basic structure to cope with rainy periods or to use them more efficiently, low levels of treatment and use of wastewater, degradation environmental resources, climate change, among others (Urbano et al., 2017). The Brazilian northeastern region features sedimentary basins with hundreds of oil fields, with a yearly output of approximately 44 million petroleum barrels. The Potiguar Basin is extended to the states of Rio Grande do
Norte and Ceará, whose land section may be classified as mature due to its advanced exploitation condition (Anp, 2018). Similar to many other exploration and production activities, the oil industry produces large quantities of waste and effluents. The largest volume of effluent generated in this type of activity is the "produced water" (PW), which is a mixture of naturally formed water (in greater quantity) existing below or inside the oil and gas reservoir, of re-injected water and chemicals used during the drilling, stimulation, production and oil-water separation processes (Santos et al., 2014; Drioli et al., 2015). The volume of water produced generally increases with the age of the reservoir and, in certain cases, can reach up to $98 \%$ of the total volume of fluid (Alzahrani and Mohammad, 2014). Oil/water ratio of the 1: 3 is generally known for most oil wells (Munirasu et al., 2016). 
Studies on wastewater from oil fields and its application in the soil-plant system are being developed (Burkhardt et al., 2015; Sousa et al., 2016). Actually, it may be an excellent alternative for semi-arid lands. However, its chemical composition should be analyzed since the produced water has high rates of organic and mineral contents and heavy metals, as a rule (Al-Haleem et al., 2010; Igunnu and Chen, 2014), which may negatively affect the soil and the environment as a whole.

The drip irrigation system is an important technological alternative for the efficient use of water resources in semiarid environments. It saves water and electricity, increases crop yields and minimizes losses due to evaporation, percolation and runoff, when well designed and managed, (Kilic, 2020) and risks of microbiological contamination of agricultural products (Batista et al., 2017).

The susceptibility to the clogging of emitters is a bottleneck that restricts the application and popularization of drip irrigation with wastewater. It is also strongly related to the formation of biofilms resulting from the interaction between physical, chemical and biological agents (Fernandes et al., 2014; Mesquita et al., 2016; Cunha et al., 2017; Silva et al., 2019).

Biofouling formed on the emitter's internal devices is the main cause for clogging. It actually affects hydraulic performance indexes and the efficiency of effluent application by the drip irrigation system (Song et al., 2017). Biofouling and fouling are two leading issues in drip irrigation emitters (Xiao et al., 2020). The narrow section and labyrinth geometry of the dripper channel result to the development of a heterogeneous flow rate behaviour within the vortex zones, which enhances the fouling mechanisms (Lequette et al., 2020).

Fouling is the accumulation of unwanted material on surfaces that can be divided into four categories: (1) particle fouling by sedimentation of particles and macro-molecules; (2) organic fouling with the sedimentation of organic materials; (3) chemical precipitate due the precipitation of low-solubility salts; and (4) biological fouling (Biofouling) occuring by adherenceldetachment of microorganisms to the inner surfaces of pipes and drippers comprising the irrigation system and the development biofilms (Katz et al., 2014).

Two important impacts are usually occurred from the clogging of drip irrigation system emitters. They are changes in the design flow rate and the increase in the flow variation coefficient (Fernandes et al., 2014; Mesquita et al., 2016; Cunha et al., 2017), which directly interfere with water distribution uniformity. Through a simulation study, López-Mata et al. (2010) proved that the increase in the uniformity of water distribution results in productivity increase of the corn crop.

A number of factors on the effects of this residue on the hydraulic performance of drip irrigation systems such as the periods of water scarcity in the northeastern semiarid, the large volume of water produced generated from oil exploration in the region and the lack of information in Brazil and in the world have made the development of this research necessary and important.

Current assay investigates the flow rate changes of non-selfcompensating drippers in the application of dilutions of treated water produced by oil exploration in the Brazilian semiarid region.

\section{Results and Discussion}

Flow rate (F) behavior of non-self-compensating drippers applied dilutions of treated water produced by oil exploration Figure 1 shows the flow rates (F) of the drip units equipped with the three types of non-self-compensating emitters operating with dilutions of treated produced water for $160 \mathrm{~h}$. There was an increase in the levels of clogging and emitters flow rate change in dilutions with greater proportions of treated produced water in relation to groundwater in contrast to the results presented by Batista et al. (2014), where the application of greater proportions of groundwater in relation to the swine effluent potentiated the clogging of emitters in the drip units that operated for $160 \mathrm{~h}$. This fact is attributed to the physicalchemical and microbiological composition of the swine effluent, which presents a risk of clogging emitters by microbiological agents, greater than that of treated produced water.

We noticed in the $\mathrm{G} 1$ emitter, that the dilutions influenced the flow rate oscillations over $160 \mathrm{~h}$ (Figure $1 \mathrm{~A})$. This is probably due to the agents that cause clogging (Table 5) and movement of the lateral lines at the time of the evaluations, which enabled the expenditure of fragments of the bioincrustration inside the emitters and the lateral lines.

In the D1 and D4 dilutions, there was only an increase in the flow rate after the initial time of $0 \mathrm{~h}$, with a maximum flow increase of 7.78 and $7.65 \%$, respectively, both in $40 \mathrm{~h}$ time. After the initial time of $0 \mathrm{~h}$, the dilutions D2 and D5 provided an increase in the flow rate in the 40 and $80 \mathrm{~h}$ times and a reduction in the flow rate in the 120 and $160 \mathrm{~h}$ times. We noted that the maximum flow rate was reached at $80 \mathrm{~h}$ in the values of 2.04 and $1.58 \%$, while the maximum flow rate reductions were $1.51 \%$ at $120 \mathrm{~h}$ and $14.31 \%$ at $160 \mathrm{~h}$ for D2 and D5, respectively. In the D3 dilution, there was only a reduction in the flow rate after the initial time of $0 \mathrm{~h}$, with the maximum flow rate reduction in the value of $5.41 \%$ at $120 \mathrm{~h}$. These results differ from those found by Cunha et al. (2017), where the same emitter G1 applied a dilution of $33 \%$ of dairy effluent in $67 \%$ of water supply for 200 $h$. There was only a decrease in the flow rate, when the flow rate of the initial time is compared to the others. We noted that the maximum flow rate reduction occurred at $160 \mathrm{~h}$ (10.49\%). Fernandes et al. (2014) studied the cashew nut effluent and reported a decrease in the flow rate of non-self-compensating emitter of $1.65 \mathrm{~L} \mathrm{~h}^{-1}$ over time, where the maximum flow rate reduction was $42 \%$ at $160 \mathrm{~h}$. In the work of Marque et al. (2016) with a $50 \%$ dilution of dairy effluent in $50 \%$ of water supply, the same emitter $\mathrm{G} 1$ showed a reduction and an increase in flow over the $160 \mathrm{~h}$ of operation. However, the maximum flow reduction occurred at $160 \mathrm{~h}$ (7.55\%).

In the $\mathrm{G} 2$ emitter, greater fluctuations in flow rates were noted over time in relation to the $\mathrm{G} 1$ and $\mathrm{G} 3$ emitters. In addition, there was greater interference from the dilutions of treated water produced in the process of clogging the emitters and, consequently, in the flow rate modification (Figure 1B).

Dilutions D1, D4 and D5 caused both an increase and a reduction in flow rate over time. In D1, there was an increase in flow rate, after the initial time of $0 \mathrm{~h}$, reaching the maximum flow rate increase at $80 \mathrm{~h}$ (3.67\%); while the flow rate decreased after 120 $\mathrm{h}$, reaching the maximum reduction at $160 \mathrm{~h}(2.66 \%)$. 
D4 and D5 had the maximum flow rate increases at $40 \mathrm{~h}$ (3.69 and $3.00 \%$ ). After $80 \mathrm{~h}$, there was a decrease in flow rate, reaching the maximum reduction at $160 \mathrm{~h}$ (8.40 and 31.33\%). The D2 dilution only provided an increase in flow rate over time, with the maximum increase at $80 \mathrm{~h}(5.31 \%)$. In the D3 dilution, there was only a reduction in flow rate, after the initial time $(0$ h), presenting a maximum flow rate reduction at $160 \mathrm{~h}(8.93 \%)$. Cunha et al. (2017) only reported a reduction in the flow rate of the same $\mathrm{G} 2$ emitter by applying a dilution of $33 \%$ of dairy effluent in $67 \%$ of water supply, when establishing a comparison between the initial flow rate and that of other times, with maximum flow rate reduction at $80 \mathrm{~h}(17.50 \%)$. The work developed by Marques et al. (2016) with the G2 emitter applied a $50 \%$ dilution of dairy effluent in $50 \%$ water supply for $200 \mathrm{~h}$. They showed a decrease in flow rate, when compared the initial time with the others, with maximum reduction at $120 \mathrm{~h}$ (20.63\%).

there was also a change in flow rate in the $\mathrm{G} 3$ emitter over time, mainly in dilutions with greater proportions of treated produced water in relation to groundwater (Figure 1C). In dilutions D1, D3, D4 and D5, there was both an increase and a reduction in flow rate, while in D2 there was only a reduction in flow rate over time. In D1 and D5, there was a maximum increase in flow at 40 h $(6.35$ and $0.03 \%)$, while it decreased after $80 \mathrm{~h}$, showing a maximum reduction at $160 \mathrm{~h}$ ( 3.78 and $11.73 \%)$. The $\mathrm{D} 2$ dilution provided a decrease in flow rate, after the initial time of $0 \mathrm{~h}$, with maximum flow rate reduction at $160 \mathrm{~h}$ (4.31\%). In the D3 dilution, there was a maximum increase in flow rate at $40 \mathrm{~h}$ $(0.28 \%)$, while after $80 \mathrm{~h}$ the flow rate decreased and reached its maximum reduction at $120 \mathrm{~h}(8.01 \%)$. After the initial time $(0$ $\mathrm{h})$, the D4 dilution showed an increase in the flow rate, with the maximum increase at $80 \mathrm{~h}(1.32 \%)$, while after $120 \mathrm{~h}$ the flow rate was decreased and reached the maximum reduction at 160 h $(11,00 \%)$. Different results were presented by Marques et al. (2016) and Cunha et al. (2017) who used the same G3 emitter for dilution of $50 \%$ of dairy effluent with $50 \%$ of water supply and $33 \%$ of dairy effluent with $67 \%$ of water supply for $200 \mathrm{~h}$, respectively. They showed a decrease in flow rate over time, when comparing the flow rate in the initial time $(0 \mathrm{~h})$ with others, with a maximum flow rate reduction at $120 \mathrm{~h}$, of 17.75 and $26.19 \%$, respectively.

\section{Flow rate coefficient of variation (FCV) behavior of non-self- compensating drippers applied dilutions of treated water produced by oil exploration}

Figure 2 shows the flow rate variation coefficient (FCV) values of the drip units equipped with three types of non-selfcompensating emitters applying dilutions of water produced during $160 \mathrm{~h}$. The FCV is a hydraulic performance indicator that detects the obstruction of emitters when its value increases over the time of operation and its classification changes from good $(\mathrm{FCV} \leq 10 \%)$ to reasonable $(10 \%>\mathrm{FCV} \leq 20 \%)$ or unacceptable (FCV > 20\%) (Asabe, 2008; Costa et al., 2019). It was also found that D5 was the treatment that most influenced the increase in FCV, and consequently, the obstruction of the emitters over the operation time of the irrigation units. This fact is probably due to the greater hardness of the effluent in D5 (Table 5), which along with the $\mathrm{pH}>7.0$, contributed the reduction of calcium solubility and the formation of calcium carbonate precipitates that lodged inside the labyrinths of emitters (Cunha et al., 2020).
In the drip units with emitter G1 (Figure 2A) we noticed that the treatments D1 to D4 presented smaller oscillations in the values of FCV throughout the experimental period. However, D5 presented a more significant increase of the FCV after $120 \mathrm{~h}$ of operation. The FCV values of treatments D1 to D4, were less than $10 \%$ over the $160 \mathrm{~h}$ of operation, which was classified as good Asabe (2008). Cunha et al. (2017) tested the non-selfcompensating type of emitter for $200 \mathrm{~h}$ using a dilution of $33 \%$ of dairy effluents plus $67 \%$ of groundwater for $200 \mathrm{~h}$ as circulating fluid. They found that the FCV was less than $10 \%$ throughout the experimental period. In the D5 treatment, the FCV values were classified as good (FCV $\leq 10 \%)$ at the 0,40 and $80 \mathrm{~h}$ operating times, reasonable $(10 \%<\mathrm{FCV} \leq 20 \%)$ at the 120 $\mathrm{h}$ operating time and unacceptable (FCV $>20 \%$ ) in the $160 \mathrm{~h}$ operating time, according to the Asabe classification (2008).

Figure $2 \mathrm{~B}$ shows that the greatest oscillations of FCV was occurred in the drip units equipped with the $\mathrm{G} 2$ emitter when the $\mathrm{G} 1$ and $\mathrm{G} 3$ units were compared. The $\mathrm{G} 2$ emitter was the most susceptible to clogging among the three emitters tested, even having the shortest labyrinth length of $13 \mathrm{~mm}$ (Table 4). Silva et al. (2013) indicated that the non-self-compensating emitter of $1.65 \mathrm{~L} \mathrm{~h}^{-1}$ with the longest labyrinth length of $58 \mathrm{~mm}$, was the most susceptible to obstruction when applying effluent from the cashew nut processing, at the service pressure of 70 $\mathrm{kPa}$ for $160 \mathrm{~h}$. Classification of FCV values of Asabe (2008) explains that (a) D1 provided good values (FCV $\leq 10 \%$ ) from 0 to $120 \mathrm{~h}$, while at $160 \mathrm{~h}$ there was a change to reasonable $(10 \%<$ FCV $\leq 20 \%$ ); (b) D2 favored good values (FCV $\leq 10 \%$ ) from 0 to $160 \mathrm{~h}$; (c) D3 caused good values (FCV $\leq 10 \%$ ) at 0,40 and 120 $h$, however reasonable values $(10 \%<\mathrm{FCV} \leq 20 \%)$ at 80 and 160 h; (d) D4 allowed good values (FCV $\leq 10 \%$ ) at 0,40 and $80 \mathrm{~h}$, reasonable value $(10 \%<\mathrm{FCV} \leq 20 \%)$ at $120 \mathrm{~h}$ and unacceptable $(\mathrm{FCV} \geq 20 \%)$ at $160 \mathrm{~h}$; and e) D5 resulted in good values at 0 and $40 \mathrm{~h}(\mathrm{FCV} \leq 10 \%)$, reasonable $(10 \%<\mathrm{FCV} \leq 20 \%)$ at $80 \mathrm{~h}$ and unacceptable (FCV $\geq 20 \%$ ) at 120 and $160 \mathrm{~h}$. Cunha et al. (2017) used the same $\mathrm{G} 2$ emitter from the present study was tested. In this study, the G2 emitter applied a dilution of $33 \%$ of dairy effluent plus $67 \%$ of groundwater and it was noted, throughout the $200 \mathrm{~h}$ of operation, that the values of FCV were all classified as good (FCV $\leq 10 \%$ ). This corroborates the results obtained in treatment $D 2$ of the present study, diverging from the results found in treatments D1, D3, D4 and D5. Costa et al. (2019) used a non-self-compensating emitter of $1.65 \mathrm{~L} \mathrm{~h}^{-1}$, operating with sanitary wastewater. They revealed that after $400 \mathrm{~h}$ of application of the effluent, the FCV classification proposed by Asabe (2008) went from good to unacceptable, corroborating with the results of treatments D4 and D5 of the present study and diverging from the results found for treatments D1, D2 and D3 of the present study.

Regarding the drip units equipped with the G3 emitter, there was a greater increase in the FCV values in the D4 and D5 treatments at $160 \mathrm{~h}$, considering that in these dilutions the highest mean hardness values occurred (Table 5), an attribute that contributes to the clogging chemical of emitters by precipitates of calcium carbonate (Cunha et al., 2020). We verified in treatments D1 to D3 that the FCV values were classified as good $(\leq 10 \%)$, while in D4 and D5 the FCV values were also considered good $(\leq 10 \%)$ until $120 \mathrm{~h}$ and reasonable $(10 \%<\mathrm{CVQ} \leq 20 \%)$ at $160 \mathrm{~h}$ of operation, throughout the experimental period, according to the classification proposed by Asabe (2008). These results do not corroborate with those 
presented by Batista et al. (2016). They reported that after 160 $\mathrm{h}$ of operation, the FCV values were higher than $20 \%$ and received the unacceptable classification (Asabe, 2008) on their study with drip units, equipped with non-self-compensating emitters of 1.70 and $2.00 \mathrm{~L} \mathrm{~h}^{-1}$, subjected to service pressures of 75, 145, 215 and $285 \mathrm{kPa}$ and which applied swine effluent.

\section{Analysis of variance of flow rate (F) data and flow rate variation coefficient (FCV)}

Table 1 presents a summary of the analysis of variance of the flow (F) and flow rate variation coefficient (FCV) variables in the subdivided plot scheme. Analyzing the $F$ and FCV variables showed that the triple dilution of effluent (D) $x$ type of drippers (G) $x$ evaluation time (T) interaction was significant at $1 \%$ probability by the $\mathrm{F}$ test and the coefficients of variation of the subsubplots (CVsubsubplots) were 3.36 and 54.77\%, respectively. Silva et al. (2019) studied drip units in a split-splitplot scheme by applying sanitary wastewater for $400 \mathrm{~h}$. They showed a significant triple interaction at $1 \%$ probability by the $\mathrm{F}$ test, but with higher CV for subsubplots (8.63\%). Batista et al. (2018) studied the FCV variables on dripper units in a split-splitplot scheme operating with swine effluent proportions plus well water for $160 \mathrm{~h}$. They reported a significant triple interaction at $1 \%$ probability of $\mathrm{F}$ test, while in the present study the value of CV subsubplots was smaller (32.00\%).

\section{Analysis of regression of flow rate (F) data}

Table 2 shows the regression equations for the flow rate variable (F) as a function of the operating time (T) of the dripper units operating with the three non-self-compensating emitters (G1, G2 and G3) and the five treatments (D1, D2, D3, D4 and D5). In the drip units equipped with the $\mathrm{G} 1$ emitter, the square root regression model was the one that best fitted the $\mathrm{F}$ and $\mathrm{T}$ data for treatments D1, D4 and D5, while the mean was the best representation in D2 and D3. Marques et al. (2016) applied a drip unit equipped with the same G1 emitter, by applying a $50 \%$ dilution of dairy effluent plus $50 \%$ supply water for $200 \mathrm{~h}$. The average was the best representation for the $F$ and $T$ data, corroborating with the results from D2 and D3. The positive and negative coefficients of the square root regression equations represent the increase and decrease in flow rate over the operating time, respectively. We also noticed that the coefficients of the regression equation of D5 (0.0337 and $0.00406)$ were higher than those obtained in D1 and D4, thus indicating a greater susceptibility to clogging of G1 operating only with translated produced water (D5), where the risks of obstruction with chemical precipitates are greater due to the hardness (Table 5), especially when the $\mathrm{pH}$ of the fluid is greater than 7.0 (Cunha et al., 2020). These results differ from those found by Batista et al. (2014) with a drip unit, equipped with a non-self-compensating emitter of $1.70 \mathrm{~L} \mathrm{~h}^{-1}$, applying a proportion of $25 \%$ pig effluent plus $75 \%$ groundwater for $160 \mathrm{~h}$, where the angular coefficient of the linear model, obtained for $\mathrm{F}$ and $\mathrm{T}$ data were lower (0.000789). In the drip units that used the $\mathrm{G} 2$ emitter, the relationship between $\mathrm{F}$ and $\mathrm{T}$ was better adjusted in treatments D1 and D2 by the quadratic regression model, in D3 and D4 by the mean and in D4 by the linear regression model. These results do not corroborate with those found by Marques et al. (2016) who adjusted the square root model to the $\mathrm{F}$ and $\mathrm{T}$ data for the same type of emitter by applying a $50 \%$ dilution of dairy effluent plus $50 \%$ supply water for $200 \mathrm{~h}$. Applying the first derivative to the quadratic equations of D1 and D2 and equaling zero (0), the dependent variable $\mathrm{F}(\mathrm{dF} / \mathrm{dT}=0)$ obtained the maximum points of 66 and $81 \mathrm{~h}(\mathrm{~T}=-\mathrm{b} / 2 \mathrm{a})$, respectively. The coefficient of the linear regression equation also called the angular coefficient of the line (0.00287) expressed at the $\mathrm{G} 2$ emitter clogging rate, over the $160 \mathrm{~h}$ operating time. This result was inferior to that obtained by Fernandes et al. (2014) in their study with a drip unit, equipped with a non-self-compensating emitter of $1.65 \mathrm{Lh}^{-}$ 1 , applying effluent from cashew nut processing for $160 \mathrm{~h}$, where the clogging rate was 0.00308 . On the other hand, in drip units with $\mathrm{G} 3$ emitter the best representation of $F$ data as a function of T was the average in treatments D1, D3 and D4 and the linear regression model in D2 and D5. These results differ from those presented by Marques et al. (2016), where the quadratic model was the one that best fitted the F and T data, for the same type of emitter operating with dilution of dairy effluent for $200 \mathrm{~h}$. The angular coefficients of D2 and D5 were 0.000483 and 0.00120 , respectively, indicating a higher rate of clogging in D5. These results differ from those found by Batista et al. (2011), where the slope coefficients were $0.0024,0.00085$ and 0.0024 for drip units, equipped with a $1.70 \mathrm{Lh}^{-1}$ non-compensating emitter, which applied preliminary, secondary and tertiary sewage for $500 \mathrm{~h}$, respectively. This indicated that the type of clogging rate varies with the quality of wastewater. It should be noted that all adjusted regression models had a determination coefficient $\left(R^{2}\right)$ greater than or equal to $80 \%$. The higher the $\mathrm{R}^{2}$, the better the model and the smaller the error, and models with $\mathrm{R}^{2}$ values greater than $80.0 \%$ are more reliable for predictive purposes (Olmez, 2009).

\section{Regression of flow rate variation coefficient (FCV)}

Table 3 shows the regression equations for the variable flow rate variation coefficient (FCV) as a function of the operating time $(T)$ of the drip units operating with the three non-selfcompensating emitters ( $G 1, G 2$ and G3) and the five treatments (D1, D2, D3, D4 and D5). Analysis of the drip units equipped with the $\mathrm{G} 1$ emitter showed that the linear regression model best fitted the FCV and T data for treatments D1 and D5, while the mean was the most adequate representation in D2, D3 and D4. The linear model of D1 represented a reduction in FCV, along with T, while in D5 the angular coefficient was 0.120 and the FCV increased with the $T$, indicating a higher rate of clogging of the emitters, compared to other treatments. Silva et al. (2016) worked with drip units equipped with a non-self-compensating emitter of $1.65 \mathrm{Lh}^{-1}$, while they applied cashew nut effluent for 160 days. They found that for the service pressure of $70 \mathrm{kPa}$ the linear model was the best adjusted to FCV and T data, having a higher clogging rate (0.160). In the drip units equipped with the G2 emitter, the average represented the ratio between FCV and $T$ in the treatments D1, D2 and D3, while the linear model was the one with the best fit to D4 and D5. Comparing the angular coefficients of the linear equations of D4 (0.111) and D5 (0.282), we noticed that the clogging rate is higher in the D5 treatment. Batista et al. (2016), applied swine effluent with drip units for 160 and found that the linear model was the best to represent the ratio between FCV and $\mathrm{T}$ in a $2.00 \mathrm{Lh}^{-1}$ non-selfcompensating emitter, while subjected to a service pressure of $285 \mathrm{kPa}$ with an angular coefficient of 0.116 . In the drip units with emitter G3, the mean was the best representation of the 
Table 1. Summary of the analysis of variance from flow rate (F) and flow variation coefficient (FCV) variables in split-split-plot scheme.

\begin{tabular}{|c|c|c|c|}
\hline \multirow[t]{2}{*}{ Variation source } & \multirow[t]{2}{*}{ Degrees of freedom } & \multicolumn{2}{|c|}{ Mean square } \\
\hline & & $\mathrm{F}$ & FCV \\
\hline Dilution of effluent (D) & 4 & $0.21^{* *}$ & $508.02^{* *}$ \\
\hline Residue (a) & 8 & 0.001 & 31.7 \\
\hline Type of drippers (G) & 2 & $1.81^{* *}$ & $790.12^{* *}$ \\
\hline $\mathrm{D} \times \mathrm{G}$ & 8 & $0.027^{* *}$ & $146.51^{* *}$ \\
\hline Residue (b) & 20 & 0.003 & 40.67 \\
\hline Evaluation time ( $\mathrm{T}$ ) & 4 & $0.12^{* *}$ & $364.60^{* *}$ \\
\hline $\mathrm{D} \times \mathrm{T}$ & 16 & $0.023^{* *}$ & $162.37^{* *}$ \\
\hline $\mathrm{G} \times \mathrm{T}$ & 8 & $0.009^{* *}$ & $106.07^{* *}$ \\
\hline $\mathrm{D} \times \mathrm{G} \times \mathrm{T}$ & 32 & $0.005^{* *}$ & $39.47^{* *}$ \\
\hline Residue (c) & 122 & 0.002 & 20.98 \\
\hline General means & & 1.46 & 8.36 \\
\hline $\mathrm{CV}_{\text {plot }}(\%)$ & & 2.3 & 67.32 \\
\hline $\mathrm{CV}_{\text {subplot }}(\%)$ & & 3.72 & 76.25 \\
\hline $\mathrm{CV}_{\text {subsubplot }}(\%)$ & & 3.36 & 54.77 \\
\hline
\end{tabular}

A.

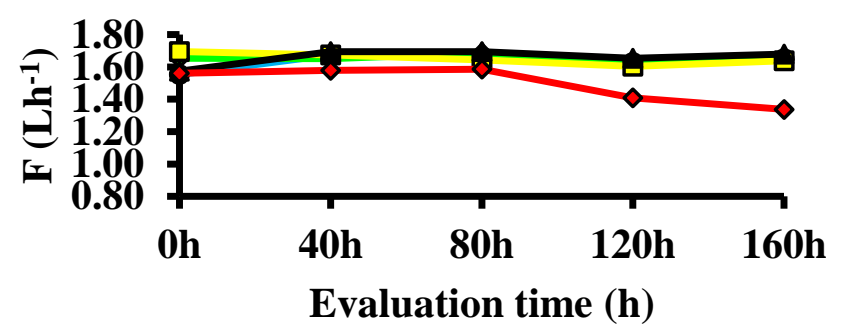

-DD1 $\diamond \mathrm{D} 2 \backsim \mathrm{D} 3 \rightarrow \mathrm{D} 4 \multimap \mathrm{D} 5$

B.
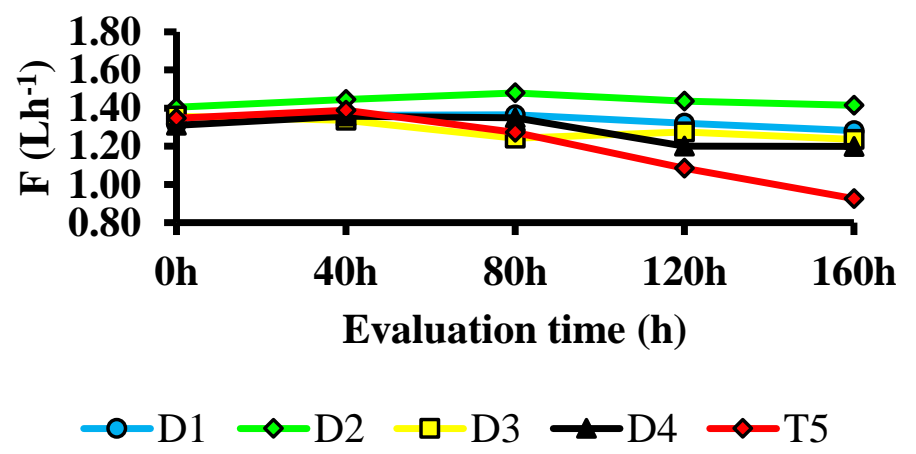

c.

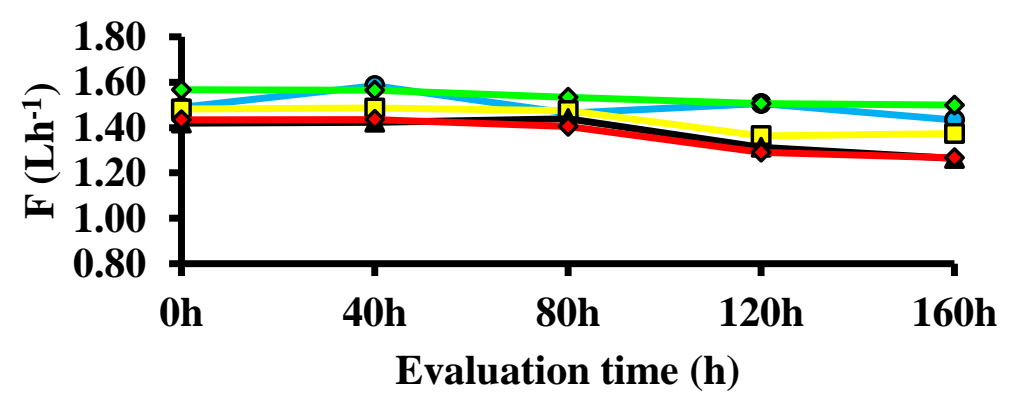

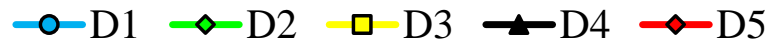

Fig 1. Flow rate $(F)$ graphs according to operation times in drip units with emitters $G 1(A), G 2(B)$ and $G 3$ (C), with dilutions of treated water produced by oil exploration. 
Table 2. Regression equations adjusted to flow rate $(F)$ variable according to operation times $(T)$ of drip units for three types of emitters (G1, G2 and G3) and five treatments (D1, D2, D3, D4 and D5) evaluated.

\begin{tabular}{|c|c|c|c|}
\hline Dripper & Treatment & Regression equation & $R^{2}$ \\
\hline \multirow[t]{5}{*}{ G1 } & D1 & $\widehat{\mathrm{F}}=1.556+0.0266^{*} \mathrm{~T}^{0,5}-0.00162^{0} \mathrm{~T}$ & 0.88 \\
\hline & $\mathrm{D} 2$ & $\hat{\mathrm{F}}=\overline{\mathrm{F}}=1.652$ & - \\
\hline & D3 & $\widehat{\mathrm{F}}=\overline{\mathrm{F}}=1.651$ & - \\
\hline & D4 & $\hat{\mathrm{F}}=1.576+0.0275^{*} \mathrm{~T}^{0,5}-0.00163^{0} \mathrm{~T}$ & 0.90 \\
\hline & D5 & $\widehat{\mathrm{F}}=1.577+0.0337^{0} \mathrm{~T}^{0,5}-0.00406^{*} \mathrm{~T}$ & 0.91 \\
\hline \multirow[t]{5}{*}{ G2 } & D1 & $\widehat{\mathrm{F}}=1.321+0.00128^{*} \mathrm{~T}-0.00000973^{*} \mathrm{~T}^{2}$ & 0.95 \\
\hline & D2 & $\widehat{\mathrm{F}}=1.406+0.00147^{*} \mathrm{~T}-0.00000902^{*} \mathrm{~T}^{2}$ & 0.86 \\
\hline & D3 & $\widehat{\mathrm{F}}=\overline{\mathrm{F}}=1.290$ & - \\
\hline & D4 & $\widehat{\mathrm{F}}=\overline{\mathrm{F}}=1.283$ & - \\
\hline & D5 & $\widehat{\mathrm{F}}=1.434-0.00287^{* *} \mathrm{~T}$ & 0.87 \\
\hline \multirow[t]{5}{*}{ G3 } & D1 & $\hat{\mathrm{F}}=\overline{\mathrm{F}}=1.495$ & - \\
\hline & $\mathrm{D} 2$ & $\widehat{\mathrm{F}}=1.573-0.000483^{* *} \mathrm{~T}$ & 0.94 \\
\hline & D3 & $\widehat{\mathrm{F}}=\overline{\mathrm{F}}=1.436$ & - \\
\hline & D4 & $\widehat{\mathrm{F}}=\overline{\mathrm{F}}=1.372$ & - \\
\hline & D5 & $\widehat{\mathrm{F}}=1.463-0.00120^{*} \mathrm{~T}$ & 0.87 \\
\hline
\end{tabular}

A.



$-\mathrm{D} 1 \backsim \mathrm{D} 2 \backsim \mathrm{D} 3 \sim \mathrm{D} 4 \sim \mathrm{D} 5$

B.

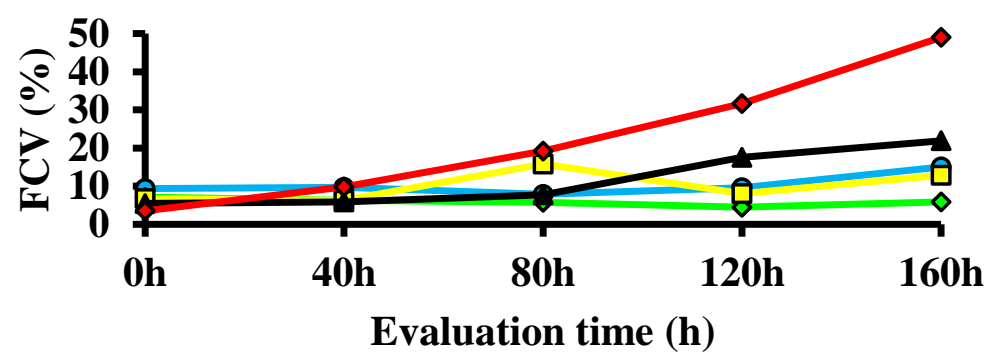

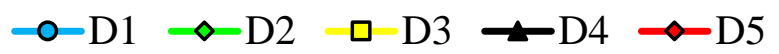

c.

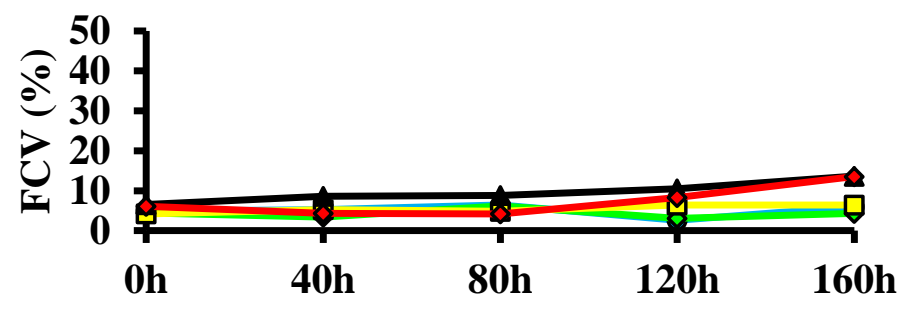

Evaluation time (h)



Fig 2. Flow coefficient of variation (FCV) graphs according to operation time in drip units with emitters G1 (A), G2 (B) and G3 (C), applying dilutions of treated water produced by oil exploration. 
Table 3. Regression equations adjusted to flow variation coefficient (FCV) variable according to operation time (T) of drip units for three types of drippers (G1, G2 and G3) and five treatments (D1, D2, D3, D4 and D5) analyzed.

\begin{tabular}{|c|c|c|c|}
\hline Dripper & Treatment & Regression equation & $\mathbf{R}^{2}$ \\
\hline \multirow[t]{5}{*}{ G1 } & D1 & $\widehat{\mathrm{FCV}}=6.807-0.01952^{*} \mathrm{~T}$ & 0.87 \\
\hline & D2 & $\widehat{\mathrm{FCV}}=\overline{\mathrm{FCV}}=6.672$ & - \\
\hline & D3 & $\widehat{\mathrm{FCV}}=\overline{\mathrm{FCV}}=3.683$ & - \\
\hline & D4 & $\widehat{\mathrm{FCV}}=\overline{\mathrm{FCV}}=5.961$ & - \\
\hline & D5 & $\widehat{\mathrm{FCV}}=2.200+0.120^{*} \mathrm{~T}$ & 0.81 \\
\hline \multirow[t]{5}{*}{ G2 } & D1 & $\widehat{\mathrm{FCV}}=\overline{\mathrm{FCV}}=10.324$ & - \\
\hline & D2 & $\widehat{\mathrm{FCV}}=\overline{\mathrm{FCV}}=5.914$ & - \\
\hline & D3 & $\widehat{\mathrm{FCV}}=\overline{\mathrm{FCV}}=9.968$ & - \\
\hline & D4 & $\widehat{\mathrm{FCV}}=2.796+0.111^{* *} \mathrm{~T}$ & 0.88 \\
\hline & D5 & $\widehat{\mathrm{FCV}}=0.0747+0.282^{* *} \mathrm{~T}$ & 0.96 \\
\hline \multirow[t]{5}{*}{ G3 } & D1 & $\widehat{\mathrm{FCV}}=\overline{\mathrm{FCV}}=4.987$ & - \\
\hline & D2 & $\widehat{\mathrm{FCV}}=\overline{\mathrm{FCV}}=4.267$ & - \\
\hline & D3 & $\widehat{\mathrm{FCV}}=4.281+0.0140^{*} \mathrm{~T}$ & 0.83 \\
\hline & D4 & $\widehat{\mathrm{FCV}}=6.401+0.0401^{* *} \mathrm{~T}$ & 0.92 \\
\hline & D5 & $\widehat{\mathrm{FCV}}=6.105-0.0835^{*} \mathrm{~T}+0.000817^{* *} \mathrm{~T}$ & 0.99 \\
\hline
\end{tabular}

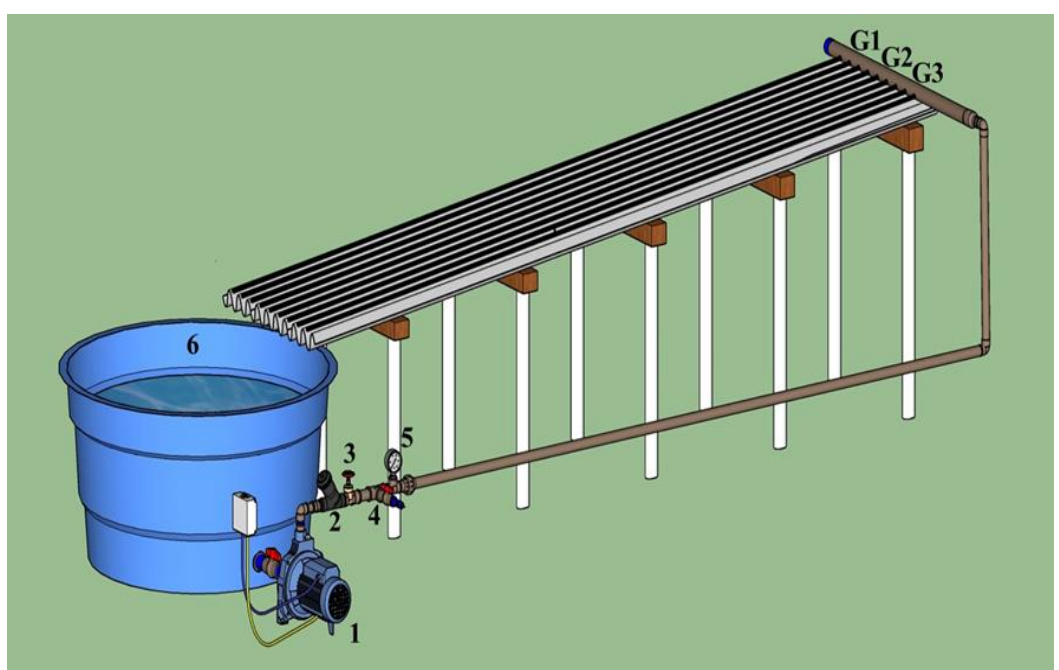

Fig 3. Bench test comprising of centrifuge pump (1), screen filter (2), valve (3), collection site for effluent samples (4), manometer (5), reservoir for the storage of diluted treated produced water (6) and non-self-compensating drippers (G1, G2 and G3).

Table 4. Characteristics of non-self-compensating drippers used in the assays: nominal flow rate (F), filtration area (FA), length of labyrinth (LL), operating pressure range (OPR) and spacing between emitters (SE) adapted from Vale et al. (2020).

\begin{tabular}{|c|c|c|c|c|c|}
\hline Drippers & $F\left(L h^{-1}\right)$ & $\mathrm{FA}\left(\mathrm{mm}^{2}\right)$ & $\mathrm{LL}(\mathrm{mm})$ & OPR (kPa) & SE (m) \\
\hline G1 & 1.60 & 34.0 & 23 & $60-100$ & 0.30 \\
\hline G2 & 1.60 & 17.0 & 13 & $65-100$ & 0.30 \\
\hline G3 & 1.70 & 6.0 & 44 & $50-300$ & 0.20 \\
\hline
\end{tabular}

Table 5. Means and standard deviations of the physical and chemical attributes of dilutions of treated water produced by oil exploration (D) adapted from Vale et al. (2020).

\begin{tabular}{|c|c|c|c|c|c|}
\hline \multirow[t]{2}{*}{ Attributes } & \multicolumn{5}{|c|}{ Treatments } \\
\hline & D1 & $\mathrm{D} 2$ & D3 & D4 & D5 \\
\hline $\mathrm{pH}$ & $8.70 \pm 0.27$ & $8.57 \pm 0.20$ & $8.61 \pm 0.23$ & $8.47 \pm 0.16$ & $8.60 \pm 0.05$ \\
\hline EC & $0.72 \pm 0.08$ & $0.75 \pm 0.16$ & $0.78 \pm 0.12$ & $0.72 \pm 0.06$ & $0.63 \pm 0.07$ \\
\hline $\mathrm{Ca}^{2+}$ & $0.50 \pm 0.27$ & $0.68 \pm 0.30$ & $0.86 \pm 0.45$ & $1.07 \pm 0.55$ & $1.05 \pm 0.94$ \\
\hline $\mathrm{Mg}^{2+}$ & $0.38 \pm 0.13$ & $0.51 \pm 0.24$ & $0.74 \pm 0.25$ & $0.65 \pm 0.51$ & $1.00 \pm 0.61$ \\
\hline $\mathrm{CO}_{3}{ }^{2-}$ & $1.60 \pm 0.44$ & $1.20 \pm 0.46$ & $1.20 \pm 0.59$ & $1.40 \pm 0.27$ & $1.40 \pm 0.30$ \\
\hline $\mathrm{HCO}_{3}^{-}$ & $3.00 \pm 0.11$ & $3.30 \pm 0.32$ & $3.40 \pm 0.38$ & $3.40 \pm 0.22$ & $3.40 \pm 0.29$ \\
\hline Hardness & $45,50 \pm 8,39$ & $69,50 \pm 8,44$ & $84,50 \pm 10,94$ & $98,00 \pm 7,95$ & $108 \pm 6,58$ \\
\hline TSS & $10 \pm 6$ & $10 \pm 5$ & $8 \pm 2$ & $12 \pm 6$ & $8 \pm 5$ \\
\hline TDS & $298 \pm 122$ & $373 \pm 97$ & $379 \pm 75$ & $319 \pm 129$ & $319 \pm 129$ \\
\hline
\end{tabular}

EC - Electric conductivity, in dS $\mathrm{m}^{-1} ; \mathrm{Ca}^{2+}$ - Calcium, in $\mathrm{mmol}_{\mathrm{c}} \mathrm{L}^{-1} ; \mathrm{Mg}^{2+}$ - Magnesium, in $\mathrm{mmol}_{\mathrm{c}} \mathrm{L}^{-1} ; \mathrm{TSS}$ - Total suspended solids, in $\mathrm{mg} \mathrm{L}^{-1}$, TDS - Total dissolved solids, in $\mathrm{mg} \mathrm{L}^{-1}$, $\mathrm{CO}_{3}^{2-}$ - Carbonate, in $\mathrm{mmol}_{\mathrm{C}} \mathrm{L}^{-1}$ and $\mathrm{HCO}_{3}-$ Bicarbonate, in $\mathrm{mmol}_{\mathrm{C}} \mathrm{L}^{-1}$. 
data of FCV and T in treatments D1 and D2, while the linear and quadratic models were best fit for treatments D3 and D4 and treatment D5, respectively. These results differ from Costa et al. (2019), where the square root model was the one that best fit the FCV and T data of a $1.65 \mathrm{Lh}^{-1}$ in non-self-compensating emitter operating with sanitary wastewater for $400 \mathrm{~h}$. Table 3 also shows that the adjusted regression models presented a coefficient of determination $\left(R^{2}\right)$ greater than or equal to $80 \%$, which is more reliable for predictive purposes according to Olmez (2009).

\section{Materials and methods}

\section{Experimental set-up}

Current assay was performed at the experimental unit of the Laboratory of Rural Constructions and Environment of the Department of Engineering and Environmental Sciences (DECAM) of the Engineering Center (CE), on the Eastern Campus of the Universidade Federal Rural do Semi-Árido (UFERSA) in Mossoró, RN, Brazil, at $5^{\circ} 12^{\prime} 13.14^{\prime \prime} \mathrm{S}$ and $37^{\circ} 19^{\prime} 26.93^{\prime \prime} \mathrm{W}$, between 26th August and 5th October 2018.

Five $8.00 \mathrm{~m}^{2}$ ( $1.00 \mathrm{~m}$ wide by $8.00 \mathrm{~m}$ long) test benches were prepared, with a wooden basis to hold the undulated fibercement tiles. Tiles were set at a $2.5 \%$ slide for the recirculation of the effluent. A $0.31 \mathrm{~m}^{2}$ reservoir was placed at the lower part of each bench. The device was locked to a drip irrigation system composed of a $0.50 \mathrm{hp}$ motor pump, a filter screen with $130 \mu \mathrm{m}$ pores, valve, a site for collecting effluent samples, a glycerin analogic manometer $(0-400 \mathrm{kPa})$, a main line measuring 32 $\mathrm{mm}$, a derived line measuring $50 \mathrm{~mm}$ and nine $8.00 \mathrm{~m}$ lateral lines.

The drip irrigation system was divided into three dripper units distributed at random on the bench test. Each dripper unit comprised of three lateral lines measuring $8.00 \mathrm{~m}$ acquired from a sole drip manufacturer. Sixteen drippers, at an equal distance from each other, were selected in each lateral line to assess distribution uniformity of the effluent. Fig. 3 shows the bench test.

The three-labyrinth-type and non-self-compensating drippers were chosen for their lowest clogging rates, highly commercialized in Brazil as shown in Table 4 (adapted from Vale et al., 2020).

Produced water was retrieved from a petroleum-producing company on the Potiguar Basin, close to Jucuri RN Brazil, rural area in the municipality of Mossoró, Brazil. After collection, the water underwent treatment with organic polymer AGEFLOC DW-3753 on the site of the assay. Underground water for dilution derived from a tubular well administered by the Water and Sewage Company of Rio Grande do Norte (CAERN).

\section{Conducting the experiment}

Water was diluted with scale pails and stored in reservoirs at the end of each test bench, according to each treatment. The following treatments were assessed: D1 - 100\% of UW (underground water), control; D2 - 90\% of UW and 10\% PW (treated produced water); D3 - $80 \%$ of UW and $20 \%$ of PW; D4 $70 \%$ of UW and $30 \%$ of PW; and D5 $-60 \%$ of UW and $40 \%$ of PW. Drip units from each bench test ran at an average of four hours a day until deadline at $160 \mathrm{~h}$, for the potential formation of incrustation in the drippers and in the lateral lines. Five evaluations on the effluent's distribution uniformity was taken during this period, at an interval of $40 \mathrm{~h}$ each, specifically at times $0,40,80,120$ and $160 \mathrm{~h}$.

Flow rate of 16 drippers selected by lateral line (totaling 48 emitters per drip) was evaluated by collecting the applied effluent volume by the dripper during the time of three minutes. Drip flow rate was determined by equation 1 :

$$
F=\frac{V}{1000 . t} .60
$$

Where, $\mathrm{F}$ is the dripper's flow rate, in $\mathrm{L} \mathrm{h}^{-1} ; \mathrm{V}$ is the volume of the collected effluent, in $\mathrm{mL}$; $\mathrm{t}$ is the effluent collection time, in $\min$.

The flow rate coefficient of variation (FCV) was calculated by flow rate data of each lateral line, according to equation 2 :

$$
F C V=100 \cdot \frac{\sqrt{\frac{\sum_{i=1}^{n}\left(q_{i}-q_{a}\right)^{2}}{n_{e}-1}}}{q_{a}}
$$

Where, FCV is flow rate coefficient of variation, in \%; $q_{i}$ is the flow rate of each dripper, in $L h^{-1} ; q_{a}$ - is the average flow rate of drippers, in $\mathrm{L} \mathrm{h}^{-1} ; \mathrm{n}_{\mathrm{e}}$ is the number of evaluated drippers.

The ASAE EP 405 standard proposes the following classification for FCV values: less than $10 \%$, good; between 10 and $20 \%$, reasonable; and greater than $20 \%$, unacceptable (Asabe, 2008). Dilution samples for each treatment were collected by the end of each evaluation for physical and chemical analyses as shown in Table 5 adapted from Vale et al. (2020). Samples were sent to the Laboratory of Soil, Water and Plant Analyses (LASAP) of UFERSA: $\mathrm{pH}$ was determined by $\mathrm{pH}$-meter; electric conductivity (EC) was determined by conductivity-meter; calcium $\left(\mathrm{Ca}^{2+}\right)$ and magnesium $\left(\mathrm{Mg}^{2+}\right)$ were determined by titrimetric method. The levels of carbonate $\left(\mathrm{CO}_{3}^{2-}\right)$ and bicarbonate $\left(\mathrm{HCO}_{3}{ }^{-}\right)$were obtained by the titrimetric method, while the hardness was obtained by adding the contents of the multivalent cations $\mathrm{Ca}^{2+}$ and $\mathrm{Mg}^{2+}$. Concentrations of total suspended solids (TSS) and total solids (TS) were calculated by the gravimetry and concentrations of total dissolved solids (TDS) were assessed by the difference between TS and TSS concentrations. The analyzes followed the recommendations of the Standard Methods for the Examination of Water and Wastewater (Baird et al., 2017).

\section{Statistical analysis}

The experiment was set up in a completely randomized design in a split-split-plot scheme with three repetitions. Having the dilutions of treated water produced by oil exploration (D1, D2, D3, D4 and D5) in the plots, the types of non-self-compensating drippers (G1 - $1.6 \mathrm{~L} \mathrm{~h}^{-1}, \mathrm{G} 2-1.6 \mathrm{~L} \mathrm{~h}^{-1}$ and $\mathrm{G} 3-1.7 \mathrm{~L} \mathrm{~h}^{-1}$ ) in the subplots and evaluations time in the subsubplots $(0,40,80,120$ and $160 \mathrm{~h}$ ).

Data on the F and FCV underwent analysis of variance by $F$ test ( $p \leq 0.01)$. Averages were compared by Tukey's test ( $p \leq 0.05)$. The regression models were selected based on the value of the coefficient of determination $\left(R^{2} \geq 80 \%\right)$ according to Olmez (2009) and the significance of the coefficients of the regression equation using the " $t$ " test $(p \leq 0.10)$. 


\section{Conclusion}

The G3 emitter was the most resistant to clogging by chemical agents, presenting smaller oscillations over the operating time of hydraulic indicators flow rate and flow rate variation coefficient. The dilutions D2 (90\% of groundwater plus $10 \%$ of treated produced water) and D3 (80\% of groundwater plus $20 \%$ of treated produced water) provided the lowest losses in hydraulic performance in the drip units.

The highest rates of clogging was occurred in the $\mathrm{G} 2$ emitter operating in the D5 dilution (60\% of groundwater plus $40 \%$ of treated produced water).

\section{Acknowledgments}

The present study was carried out with support of the Coordenação de Aperfeiçoamento de Pessoal de Nível Superior - Brazil (CAPES) - Financing Code 001 and Conselho Nacional de Desenvolvimento Científico e Tecnológico (CNPq, process 470020/2011-3) for financial support.

\section{References}

Al-Haleem AA, Abdulah HH, Saeed EA (2010) Components and treatments of oilfield produced water. Al-Khawarizmi Eng J. 6:(1)24-30.

Alzahrani S, Mohammad AW (2014) Challenges and trends in membrane technology implementation for produced water treatment: a review. J Water Process Eng. 4: 107-133.

Anp (2018) - Anuário estatístico brasileiro do petróleo, gás natural e biocombustíveis 2018. Disponível em: http://www.anp.gov.br. Acesso em: 20 de dez. de 2018.

Asabe (2008) - American Society For Agricultural Engineering ASAE EP 405.1 Design and installation of microirrigation systems. Asabe. St. Joseph. 5.

Baird RB, Eaton AD, Rice EW (2017) Standard methods for the examination of water and wastewater. 23rd edn. Apha-AwwaWpcr. Washington. 1504.

Batista AA, Dutra I, Carmo FF, Izidio NSC, Batista RO (2017) Quality in papaya fruit produced with treated domestic sewage. Rev Ciênc Agron. 48(1): 70-80.

Batista RO, Oliveira RA, Cunha ME, Cunha RR, Portela JC, MT Gurgel (2018) Flow rate variation and biological agents that obstruct drippers of swine effluent. Comun Sci. 9(2): 125-132.

Batista RO, Oliveira RA, Figueiredo VB, Silva KB, Ferreira DAC (2014) Vazão de gotejadores com distintos tempos de irrigação aplicando água residuária de suinocultura e água de abastecimento. Eng Agríc. 34(6):1283-1295.

Batista RO, Oliveira RA, Santos DB, Cunha FF, Medeiros SS (2016) Modelos empíricos da aplicação de água residuária de suinocultura por gotejadores sob pressões de serviço. Irrig. 21(4):648-661.

Batista RO, Soares AA, Moreira DA, Feitosa AP, Bezerra JM (2011) Influência de diferentes qualidades de esgoto domestico na vazão de gotejadores. Rev Caatinga. 24(3):128134.

Bichai F, Polo-López MI, Ibañez PF (2012) Solar disinfection of wastewater to reduce contamination of lettuce crops by Escherichia coli in reclaimed water irrigation. Water Res. 46(18): 6040-6050.
Bressiani DA, Gassman PW, Fernandes JG, Garbossa LHP, Srinivasan R, Bonumá NB, Mendiondo EM (2015) Review of soil and water assessment tool (SWAT) applications in Brazil: challenges and prospects. Int J Agr Biol Eng. 8(3): 9-35.

Burkhardt A, Gawde A, Cantrell CL, Baxter HL, Joyce BL, Stewart Jr. CN, Zheljazkov VD (2015) Effects of produced water on soil characteristics, plant biomass, and secondary Metabolites. J Environ Qual. 44(6):1938-1947.

Costa DO, Vale HSM, Batista RO, Silva PCM, Lemos Filho LC, Santos DB (2019) Suscetibilidade ao entupimento de gotejadores aplicando água residuária doméstica tratada. Rev em Agrone e Meio Ambient. 12(4): 1251-1266.

Cunha JLO, Silva SL, Batista RO, Marques BCD, Coelho DCL, Silva KB (2020) Monitoramento da bioincrustação em fitas gotejadoras aplicando água com distintas temperaturas e salinidades. Irrig. 25(1):1-13.

Cunha ME, Marques BCD, Batista RO, Costa AG, Cunha RR, Andrade ATS (2017) Obstrução de gotejadores operando com efluente de laticínio diluído. Rev Bras Agric Irrig. 11(4):15171527.

Drioli E, Ali A, Lee YM, Al-Sharif SF, Al-Beirute M, Macedonio F (2015) Membrane operations for produced water treatment. Desalination Water Treat. 57(31): p. 14317-14335.

Fernandes RKA, Batista RO, Silva SKC, Oliveira JF, Paiva LAL (2014) Vazão de gotejadores aplicando água residuária da castanha de caju. Irrig. 19(4):585-597.

Igunnu ET, Chen GZ (2014) Produced water treatment technologies. Int J Low-Carbon Tech. 9(3):157-177.

Katz S, Dosoretz C, Chen Y, Tarchitzky J (2014) Fouling formation and chemical control in drip irrigation systems using treated wastewater. Irrig Sci. 32: 459-469.

Kilic, M (2020) A new analytical method for estimating the 3D volumetric wetting pattern under drip irrigation system. Agric Water Manag. 228: 105898.

Lequette K, Ait-Mouheb N, Wéry N (2020) Hydrodynamic effect on biofouling of milli-labyrinth channel and bacterial communities in drip irrigation systems fed with reclaimed wastewater. Sci Total Environ. 738: 139778.

López-Mata E, Tarjuelo JM, De Juan JA, Ballesteros R, Domínguez A (2010) Effect of irrigation uniformity on the profitability of crops. Agric Water Manag. 98(1): 190-198.

Marques BCD, Cunha VT, Cunha VT, Silva KB, Batista RO (2016) Desempenho de gotejadores operando com água residuária de laticínios em escala laboratorial. Irrig. 21(1):140-155.

Mesquita FO, Alves SMC, Batista RO, Dantas TB, Di Souza L (2016) Drip units operating with dilute landfill leachate. Rev Caatinga. 29(1): 163-172.

Munirasu S, Haija MA, Banat F (2016) Use of membrane technology for oil field and refinery produced water treatment - A review. Process Saf Environ. 100: 183-202.

Olmez, T (2009) The optimization of $\mathrm{Cr}(\mathrm{VI})$ reduction and removal by electrocoagulation using response surface methodology. J Hazard Mater. 162(2-3): 1371-1378.

Santos EV, Rocha JHB, Araújo DM, Moura DC, Martínez-Huitle CA (2014) Decontamination of produced water containing pretoleum hydrocarbons by electrochemical methods: a minireview. Environ Sci Pollut R. 21(14): 8432-8441.

Silva KB, Batista RO, Coelho DCL, Marques BCD, Mesquita FO, Cunha JLO (2019) Vazão de gotejadores aplicando esgoto sanitário tratado e prevenção do entupimento com 
catalisador enzimático. Rev em Agrone e Meio Ambient. 12(2): 679-699.

Silva KB, Batista RO, Mesquita FO, Coelho DCL, Santos WO (2016) Empirical models for performance of drippers applying cashew nut processing wastewater. Rev Caatinga. 29(2):405414.

Silva KB, Silva Júnior MJ, Batista RO, Santos DB, Barbosa Filho $\mathrm{S}$ (2013) Desempenho de gotejadores operando com efluente da castanha de caju sob distintas pressões de serviço. Rev Ceres. 60(3):339-346.

Song $\mathrm{P}$, Li Y, Zhou B, Zhou C, Zhang Z, Li J. Controlling mechanism of chlorination on emitter bio-clogging for drip irrigation using reclaimed water. Agric Water Manag. 184:36-45.
Sousa AF, Crisostomo LA, Weber OB, Escobar MEO, Oliveira TS (2016) Nutrient content in sunflower irrigated with produced water. Rev Caatinga. 29(1):94-100.

Urbano VR, Mendonça TG, Bastos RG, Souza CF (2015) Physicalchemical effects of irrigation with treated wastewater on Dusky Red Latosol soil. Rev Ambient Água. 10(4):737-747.

Vale HSM, Costa DO, Batista RO, Oliveira FA, Medeiros JF, Coelho DCL (2020). Distribution uniformity in drip units applying dilutions of treated water produced by oil exploration. Rev Bras Eng Agríc Ambient. 24(6): 394-401.

Xiao Y, Liu Y, Ma C, Muhammad T, Zhou B, Zhou Y, Song P, Li Y (2020) Using electromagnetic fields to inhibit biofouling and scaling in biogas slurry drip irrigation systems. J Hazard Mater. 401: 123265. 